\title{
Neoproterozoic Rare Element Pegmatites from Gitarama and Gatumba Areas, Rwanda: Understanding Their $\mathrm{Nb}$-Ta and $\mathrm{Sn}$ Mineralisation
}

\author{
Jean de Dieu Ndikumana ${ }^{1,2,3 *}$, Anthony Temidayo Bolarinwa², Gabriel Oladapo Adeyemi² \\ ${ }^{1}$ Institute of Life and Earth Sciences, Pan African University, Ibadan, Nigeria \\ ${ }^{2}$ Department of Geology, University of Ibadan, Ibadan, Nigeria \\ ${ }^{3}$ Department of Mining Regulation and Inspection, Rwanda Mines, Petroleum and Gas Board (RMB), Kigali, Rwanda \\ Email: *jndikumana0245@stu.ui.edu.ng
}

How to cite this paper: de Dieu Ndikumana, J., Bolarinwa, A.T. and Adeyemi, G.O. (2019) Neoproterozoic Rare Element Pegmatites from Gitarama and Gatumba Areas, Rwanda: Understanding Their Nb-Ta and $\mathrm{Sn}$ Mineralisation. Open Journal of Geology, 9, 1069-1083.

https://doi.org/10.4236/ojg.2019.913106

Received: November 15, 2019

Accepted: December 27, 2019

Published: December 30, 2019

Copyright $\odot 2019$ by author(s) and Scientific Research Publishing Inc. This work is licensed under the Creative Commons Attribution International License (CC BY 4.0).

http://creativecommons.org/licenses/by/4.0/

\begin{abstract}
The aim of this work was to study the petrography, geochemistry of the pegmatites, their relationship to the mineralisation in Gitarama and Gatumba areas, and current processes that occurred after the primary emplaced neoproterozoic rare element pegmatites. Previous works on pegmatites were geochemistry and geological maps which are not enough for focused exploration and mine planning. Therefore, geological, petrographic, geochemical studies of neoproterozoic rare element pegmatites of Gatumba and Gitarama areas in relation to their mineralisation were carried out. The samples were analysed for mineral assemblages by petrographic light microscope; major elements by ICP AES; trace and rare earth elements by ICP MS. Petrographic studies revealed the mineral assemblages included quartz, microcline, biotite and major muscovites, which implied that there was the process of muscovitisation occurred after the primary emplacement of pegmatites. The results of geochemical analysis revealed that the silica content (in wt\%) ranges from $59.5-80.5$ with an average of 67.13 (in wt $\%$ ) for the weathered pegmatite in Gatumba area ,and high percentages of $\mathrm{SiO}_{2}$ (in wt\%) range 73.9 - 75.0 with an average of 73.15 (in wt\%) for fresh pegmatite in Gitarama area. The pegmatites from Gatumba area were altered and much enriched in $\mathrm{Rb}$ (227 $3460 \mathrm{ppm}), \mathrm{Cs}(2.59-24.7 \mathrm{ppm}), \mathrm{Ta}(2.6$ - $268 \mathrm{ppm}), \mathrm{Li}(40-9224 \mathrm{ppm}), \mathrm{W}$ $(240-10,000 \mathrm{ppm}), \mathrm{Nb}(13-517 \mathrm{ppm}), \mathrm{Sn}(24-8870 \mathrm{ppm})$. Their enrichment is commonly used as a marker of a magmatic-hydrothermal alteration. Conversely, the pegmatites from Gitarama area showed the low to moderate concentrations in $\mathrm{Rb}(321-337 \mathrm{ppm})$, Cs (5.47 - $5.62 \mathrm{ppm})$, Ta (1.3 - 1.6 ppm), Li ( 20 ppm), W (5540 - 6410 ppm), Nb (3.9 - 4.3 ppm), Sn (28 - 44
\end{abstract}


ppm). The variation plot of ratios: $\mathrm{Al}_{2} \mathrm{O}_{3} /\left(\mathrm{Na}_{2} \mathrm{O}+\mathrm{K}_{2} \mathrm{O}\right)$ versus $\mathrm{Al}_{2} \mathrm{O}_{3} /(\mathrm{CaO}+$ $\left.\mathrm{Na}_{2} \mathrm{O}+\mathrm{K}_{2} \mathrm{O}\right)$ for the pegmatites from study areas are higher than one $(\mathrm{A} / \mathrm{NK}$ vs. A/CNK > 1) indicating peraluminous, the other samples of pegmatites indicated metaluminous $(\mathrm{A} / \mathrm{NK}>1$ and $\mathrm{A} / \mathrm{CNK}<1)$. REE abundance from whole rock analysis of pegmatites of Gatumba and Gitarama areas is low to moderate with the $\Sigma$ REE varying between $12.1-72.78 \mathrm{ppm}$ and $45-54.37$ ppm respectively, signifying low to medium form of enrichment. The pegmatite from Gatumba and Gitarama areas showed the $\mathrm{K} / \mathrm{Rb}$ ratios ranging from 15.74 to 80.26 and from 190.41 to 199.39 respectively. As the pegmatite samples show $\mathrm{K} / \mathrm{Rb}$ ratios less than 100 are commonly accepted for mineralization, therefore the pegmatites from Gatumba area were found mineralised, conversely to the pegmatite samples from Gitarama area, which were found barren.

\section{Keywords}

Pegmatites, Petrography, Geochemistry, Gitarama, Gatumba

\section{Introduction}

Pegmatitic rocks are very coarse-grained crystalline rocks which, in places, contain large crystals of feldspars, quartz or micas that render the felsic lithology to strongly contrast with compositionally similar granites often lying in their close vicinity [1]. Pegmatitic rocks are formed during magmatic segregation of granitic magmas in which the residual melt can be enriched in rare earth elements and heavy metals [2] [3]. Pegmatites often contain some elements such as niobium, tantalum, tin, tungsten, and beryllium and may contain semi-precious gemstones such as beryl, garnet and tourmaline [4].

The major mineral resources mined in Rwanda include columbite-tantalite and cassiterite which primarily occur in pegmatite, quartz veins, greisen and alluvial/eluvial deposits [5]. The precise characteristics of these pegmatites remain elusive. In an attempt to elucidate this, several workers have studied the geological setting and mineralisation potential of these pegmatites [6] [7] [8] [9]. Most deposits in Rwanda are not well developed, due to the lack of adequate geologic studies such as in the Gatumba and Gitarama areas. Some information was provided on the geochemistry of pegmatites in the area [10]. The insufficient geologic study and mineralisation relationship have made these areas less attractive to mining investors. Tantalum, Tin and Tungsten (3Ts) mineral exploration in the areas was largely based on colonial history of primary, alluvial and eluvial materials, with concentrations estimated from panned concentrates by handpicking, washing and weighing. Mineralised and barren pegmatites have not yet been previously delineated in the southern (Gitarama) and western (Gatumba) areas of Rwanda. This has been the pivotal motivation in the study areas.

\section{Geological Settings}

Kibara (KIB) and Karagwe Ankolean (KAB) Belts are famous geological features 
recognised in eastern central Africa [11]. KIB and $\mathrm{KAB}$ evolved between the pre-mesoproterozoic domains such as the Archaean Tanzanian craton to the east, Archaean-paleoproterozoic Congo craton to the west and north, and Bangweulu block to the south.

The KAB cuts across the Burundi, Rwanda, north-west Tanzania, south-west Uganda up to the Kivu Maniema region in Democratic Republic of Congo (RDC). Conversely, the KIB extends to south-west Katanga region including Kibara area near Mitwaba town in DRC.

The geology of Rwanda is dominated by mesoproterozoic rocks $(1.6-1.0 \mathrm{Ga})$ that were intruded by two generations of granites: $986 \mathrm{Ma}$ and $1375 \mathrm{Ma}$ [11] and the neoproterozoic pegmatite intrusion dated approximately at $965 \mathrm{Ma}$ [7].

In Rwanda, the youngest granite is responsible for the economic mineralization of 3Ts (Tin-Tantalum and Tungsten) hosted in pegmatites, quartz veins, and in alluvial and eluvial deposits [11]. The sediments within Rwanda have been subdivided into four stratigraphic groups from oldest to the youngest, which are Gikoro, Pindura, Cyohoha and Rugezi groups. The Gitarama and Gatumba areas are situated in the southern and western provinces of Rwanda, about $50 \mathrm{~km}$ west of Kigali. Gatumba is considered as a representative district for the study of pegmatite mineralisation in the KAB. Unaltered pegmatite rocks in the Gitarama area dominantly consist of microcline, $\mathrm{K}$-feldspar, quartz and muscovite. The Gatumba area is characterised by the presence of numerous rare-metal pegmatites, which are variably mineralised in columbite-tantalite and/or cassiterite. Beryl, spodumene, tourmaline, apatite, amblygonite and rare phosphates are the most important accessory minerals [12]. Lithostratigraphically, the mesoproterozoic rocks of the Gitarama and Gatumba areas belong to the Akanyaru Supergroup which consists of Gikoro, Pindura, Cyohoha and Rugezi groups [13]. The Gatumba and Gitarama areas span Gikoro and Pindura groups which are lithologically composed of alternation of mesoproterozoic phyllites and quartzites (Figure 1) characterized by a varying metamorphic degree [14]. The difference in metamorphic grade has been explained by contact metamorphism due to the intrusion of the S-type granitic massifs. The sedimentary rocks are intruded by different lithological units such as felsic and subordinate mafic rocks [11].

At a regional scale, pegmatites vary from muscovite-biotite-feldspar-quartz to muscovite-feldspar-quartz-bearing from Gitarama towards Gatumba village [12]. The second variant appears to have been affected by intense hydrothermal alteration and $\mathrm{Nb}-\mathrm{Ta}-\mathrm{Sn}$ mineralisation. Referring the classification schemes [15] [16]. The most evolved pegmatites belong to the Lithium-Caesium-Tantalum (LCT) family based on the rare element association, and more specifically to the rare element pegmatite class. Based on the rare element mineralogy, they include representatives of the beryl-type (beryl columbite subtype), complex-type (spodumene subtype), and albite-spodumene type [10]. The rare element pegmatite from Gatumba area has attracted different mining companies for exploitation of niobium-tantalum and tin minerals. 


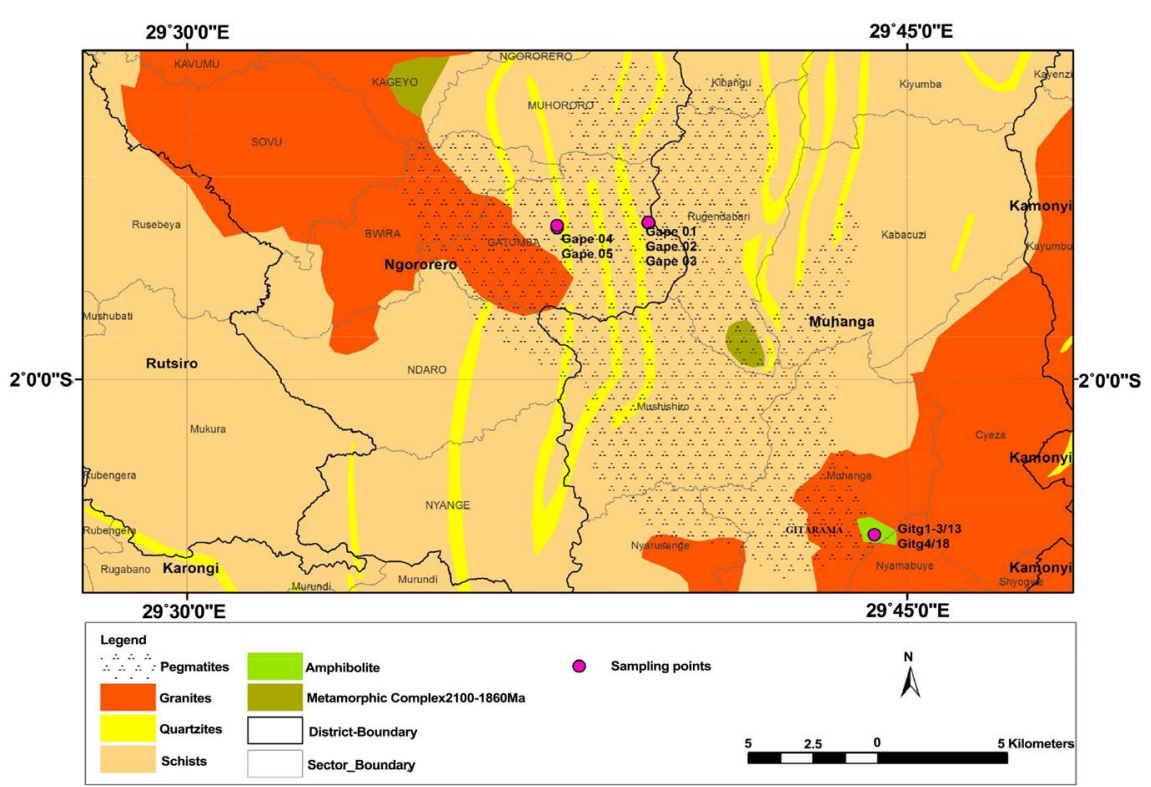

Figure 1. Simplified geological map of Gitarama and Gatumba areas. Source: (modified after [17]).

\section{Materials and Methods}

Field and petrographic characterization were used to understand the detail mineral assemblages, alteration and paragenetic relationships. Samples were first described macroscopically and a preliminary paragenetic sequence was reconstructed. Twenty thin sections of representative rock samples were prepared for petrographic investigation at the department of Geology, University of Ibadan, Ibadan, Nigeria. The rock samples were cut into small chips, thinned down and mounted on glass plate. This was placed on a hot plate to dry. Araldite was used to glue the dry chip on a glass and left overnight to dry. Further reduction in size to approximately $30 \mu \mathrm{m}$ was achieved using silicon carbide to produce a very thin layer that was covered with Canada basalm and placed on hot plate to dry. Excess Canada basalm was washed off with acetone to obtain a clean thin section. The thin sections produced from rocks were examined under petrographic microscope at a total magnification of 100X. Photomicrographs of the slides were taken and processed. The thin sections were observed with a transmitted polarized light microscope.

A total of 14 rock samples of pegmatites (9), granite (3) and amphibolite (2) were used for whole rock geochemical analysis at Australian Laboratory Services (ALS), Johannesburg, South Africa. The rock samples were pulverised for $50 \mathrm{~g}$ of powders of $85 \%$ and passing 75 microns for whole rock geochemical composition where the concentration of major and trace elements were determined by method of Atomic Emission Spectrometry (ICP-AES) and Inductively Coupled Plasma-Mass Spectrometry (ICP-MS) respectively. A prepared sample of $0.100 \mathrm{~g}$ was added to the lithium metaborate flux, mixed well and fused in a furnace at $1000^{\circ} \mathrm{C}$. The resulting melt was then cooled and dissolved in $100 \mathrm{~mL}$ of $4 \%$ $\mathrm{HNO}_{3}$ and $2 \% \mathrm{HCl}$ solution. The ions were extracted from the plasma through a 
pinhole-sized orifice into a pumped vacuum system. The ions were also focused with an ion lens into a mass spectrometer.

\section{Results and Discussions}

\subsection{Field Occurrence}

Formation of mafic units proceeded with the first generation of biotite-muscovite granite (formerly known as $\mathrm{G}_{1-3}$ ) in Figure 2(a), which is barren. The second generation of granite, which is the youngest and formerly known as G4, fertile granite or tin-granite, was emplaced and resulted in the ores [11]. The fertile granite from Gitarama area has been proposed as the parental granite for the pegmatites in the Gatumba area, but this, however, remains a matter of debate [18]. This area showed bimodal magmatism of felsic and subordinate mafic unit of amphibolite (Figure 2(b)). Rock exposures of young granitic pegmatite intruding metasedimentary rocks can be observed in Gitarama and Gatumba areas (Figure 2(c)). The amphibolite and granitic pegmatite intrusion were emplaced at different periods during the Kibara event in central Africa. The altered pegmatite from Gatumba area (Figure 2(d)) appears to have been affected by intense hydrothermal alteration and $\mathrm{Nb}-\mathrm{Ta}-\mathrm{Sn}$ mineralisation. The primary emplacement of Sn was observed in the hydroxyl-bearing phases of the granites and mineralisation hosted in the neoproterozoic rare element pegmatite and/or quartz veins. The $\mathrm{Nb}-\mathrm{Ta}$ in the pegmatites were mostly overprinted through the precipitation reaction driven by hydrothermal fluid in the original pegmatites which were subsequently alterated during hydrothermal processes [7] [8].

\subsection{Petrography}

The pegmatite from Gitarama area was composed of quartz, plagioclase feldspars and biotites, and the pegmatites from Gatumba area showed quartz and muscovite. The granite in light petrographic observation showed biotite, quartz, and microcline whereas the amphibolites were composed of quartz, plagioclase, orthoclase and hornblendes. The major muscovites in pegmatite samples indicate a process of alteration (muscovitisation) that occurred after the primary emplaced pegmatite. This process was the one of the paragenetic sequences of columbite and cassiterite mineralisation in the Gatumba area [7]. The cross-hatch and distinct banding effect (polysynthetic) twinnings revealed the presence of microcline in K-feldspar and plagioclase feldspars respectively (Figure 3(a), Figure 3(c) and Figure 3(e)) in biotite-muscovite granite, pegmatite and amphibolite from Gitarama and Gatumba areas. The muscovites were also identified in Figure $3(\mathrm{~g})$ in weathered pegmatite from the Gatumba area. The photographs by plane polarised light showed the biotites with high relief in Figure 3(b) and Figure 3(d), and the hornblende (Figure 3(f)) while the muscovites in Figure 3(h) did not show any observation under plane polarised light. 


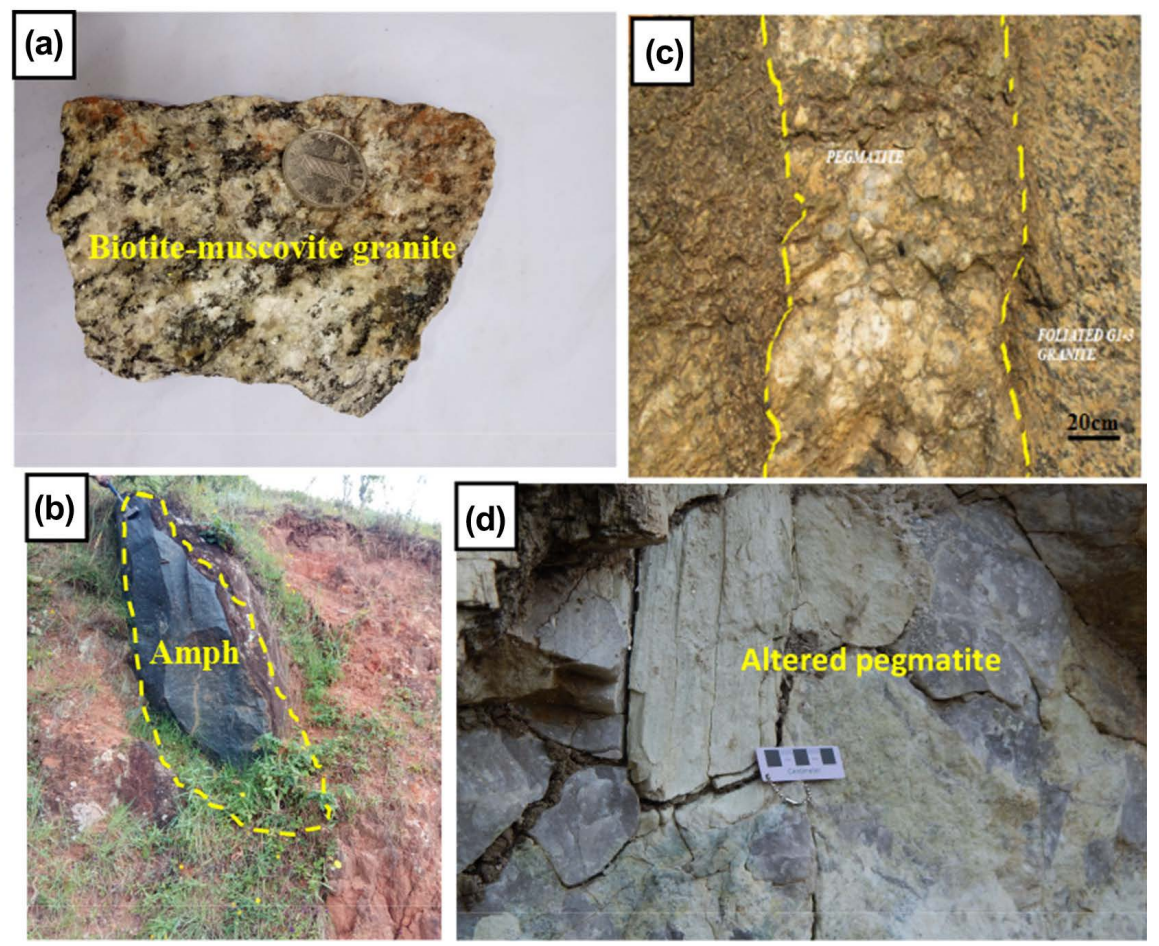

Figure 2. (a): The hand specimen of the two mica (biotite-muscovite) granite from Gitarama road section towards Gatumba concession (coin for scale). (b): Amphibolite at Gitarama area (40 $\mathrm{cm}$ hammer for scale). (c): Yellow dashed line indicates the margins of the pegmatite intruded biotite-muscovite granite at Gitarama area. (d): Altered pegmatite at Gatumba mining site.

\subsection{Whole Rock Geochemical Composition}

\subsubsection{Major Element Composition}

The whole rock composition of the pegmatites from Gitarama and Gatumba areas shows moderate to high concentrations (in wt \%) of $\mathrm{SiO}_{2}(59.5-80.5)$, $\mathrm{Al}_{2} \mathrm{O}_{3}\left(11.85\right.$ - 18.80), $\mathrm{Na}_{2} \mathrm{O}$ (0.01 - 7.18), $\mathrm{CaO}(0.19$ - 8.84). The Silica Content (in wt \%) ranges from 59.5 to 80.5 and from 73.9 to 75.0 for weathered pegmatite and fresh pegmatite samples respectively (Table 1 ). The silica content increases from mafic to felsic rocks such as the amphibolite to granite and pegmatite.

The pegmatites from Gitarama and Gatumba areas showed low to high concentration in $\mathrm{wt} \% \mathrm{~K}_{2} \mathrm{O}(0.44-10.25)$, since dominantly originated from a tholeiitic magma which has high concentration of silica linked to granite differentiation and low- $\mathrm{K}$ values. The $\mathrm{Al}_{2} \mathrm{O}_{3} /\left(\mathrm{Na}_{2} \mathrm{O}+\mathrm{K}_{2} \mathrm{O}\right)$ and $\mathrm{Al}_{2} \mathrm{O}_{3} /\left(\mathrm{CaO}+\mathrm{Na}_{2} \mathrm{O}+\right.$ $\mathrm{K}_{2} \mathrm{O}$ ) for pegmatites from Gitarama area are higher than one $(\mathrm{A} / \mathrm{NK}$ and $\mathrm{A} / \mathrm{CNK}>1$ ) indicating a peraluminous, and the other samples of pegmatites from Gatumba area in Figure 4 indicate the peraluminous and metaluminous.

\subsubsection{Trace Element Composition}

Trace elements were used to investigate the mineralisation of pegmatites from Gatumba and Gitarama areas with the higher enrichment (Table 2) ranges for Li (40 - 9240 ppm), Cs (2.59 - 11.95 ppm), Ta (2.6 - 268 pm) and Rb (181 - 3460 ppm) for the Gatumba pegmatite than Gitarama pegmatite showed Li 

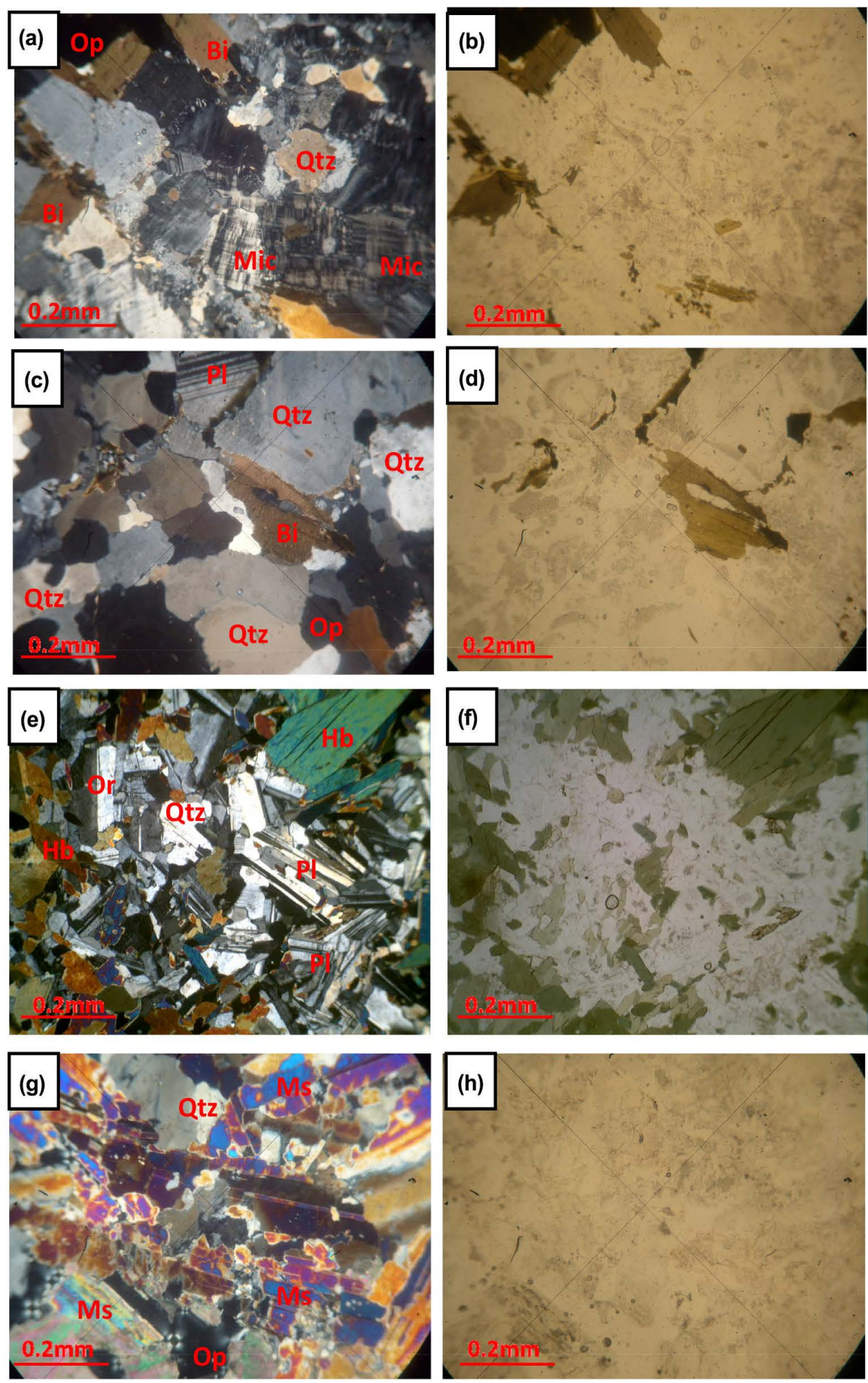

Figure 3. Thin section photomicrographs. (a): XPL, Presence of Biotite, Microcline and Quartz in biotite-muscovite granite from Gitarama area, (b): PPL; (c): XPL, the phenocrysts texture of coarse grains of quartz and existence of plagioclase feldspars and biotites in fresh pegmatite from Gitarama road section toward Gatumba area, (d): PPL; (e): XPL, dominant hornblende, Quartz and orthoclase for Amphibolite from Gitarama area, (f): PPL; (g): XPL, Muscovite, Quartz and Opaque minerals are present in the weathered pegmatite from Gatumba mining site, H: PPL. Pl: Plagioclase, Bi: Biotite, Qtz. Quartz, Ms. Muscovite, $O p$ : Opaque mineral, $H b$ : Hornblende, $O r$ orthoclase. XPL: crossed polarised light, $P P L$ : Plane polarised light. 
Table 1. Major oxides (wt\%) of pegmatites and associated rocks from Gitarama and Gatumba areas.

\begin{tabular}{|c|c|c|c|c|c|c|c|c|c|c|c|c|c|c|}
\hline \multirow[b]{2}{*}{ Sample } & \multirow[b]{2}{*}{ Gape01 } & \multicolumn{5}{|c|}{ Weathered pegmatites in Gatumba } & \multicolumn{3}{|c|}{$\begin{array}{c}\text { Fresh pegmatite in } \\
\text { Gitarama }\end{array}$} & \multicolumn{3}{|c|}{$\begin{array}{c}\text { Biotite-muscovite granite in } \\
\text { Gitarama }\end{array}$} & \multicolumn{2}{|c|}{$\begin{array}{l}\text { Amphibolite in Gi- } \\
\text { tarama }\end{array}$} \\
\hline & & Gape02 & Gape03 & Gape04 & Gape05 & Gape06 & Gipe07 & Gipe08 & Gipe09 & RG01 & RG02 & RG03 & RGA01 & RGA02 \\
\hline $\mathrm{SiO}_{2}$ & 65.3 & 59.9 & 74.0 & 80.5 & 63.6 & 59.5 & 73.9 & 74.7 & 75.0 & 71.4 & 72.4 & 71.5 & 46.1 & 46.9 \\
\hline $\mathrm{Al}_{2} \mathrm{O}_{3}$ & 13.75 & 14.65 & 12 & 11.85 & 18.80 & 14.65 & 12.75 & 13.0 & 12.95 & 14.05 & 13.80 & 13.70 & 13.05 & 12.95 \\
\hline $\mathrm{Fe}_{2} \mathrm{O}_{3}$ & 1.47 & 0.47 & 5.56 & 1.33 & 0.48 & 0.50 & 1.13 & 1.10 & 1.14 & 3.46 & 3.35 & 3.56 & 11.75 & 12.10 \\
\hline $\mathrm{MnO}$ & 0.02 & 0.12 & 0.20 & 0.01 & 0.01 & 0.12 & 0.04 & 0.04 & 0.04 & 0.04 & 0.04 & 0.04 & 0.20 & 0.21 \\
\hline $\mathrm{CaO}$ & 0.19 & 8.43 & 0.75 & 0.30 & 0.25 & 8.84 & 0.29 & 0.30 & 0.28 & 2.13 & 2.04 & 2.01 & 11.30 & 11.60 \\
\hline $\mathrm{K}_{2} \mathrm{O}$ & 0.96 & 1.22 & 1.44 & 1.75 & 10.25 & 1.24 & 7.54 & 7.73 & 7.71 & 4.49 & 4.27 & 4.28 & 0.40 & 0.38 \\
\hline $\mathrm{Na}_{2} \mathrm{O}$ & 0.25 & 7.18 & 2.01 & 4.55 & 2.18 & 7.15 & 2.08 & 2.12 & 2.09 & 3.04 & 3.04 & 3.00 & 1.33 & 1.31 \\
\hline $\mathrm{P}_{2} \mathrm{O}_{5}$ & 11.60 & 6.43 & 0.59 & 0.23 & 0.53 & 6.82 & 0.16 & 0.15 & 0.13 & 0.17 & 0.19 & 0.17 & 0.11 & 0.06 \\
\hline $\mathrm{Cr}_{2} \mathrm{O}_{3}$ & 0.004 & $<0.002$ & 0.013 & $<0.002$ & $<0.002$ & $<0.002$ & $<0.002$ & $<0.002$ & $<0.002$ & 0.010 & 0.004 & 0.004 & 0.038 & 0.041 \\
\hline $\mathrm{TiO}_{2}$ & 0.04 & 0.01 & 0.01 & 0.02 & $<0.01$ & 0.01 & 0.02 & 0.02 & 0.02 & 0.37 & 0.35 & 0.38 & 0.67 & 0.67 \\
\hline $\mathrm{MgO}$ & 0.10 & 0.03 & 0.31 & 0.07 & 0.02 & 0.04 & 0.06 & 0.06 & 0.06 & 0.79 & 0.76 & 0.78 & 8.47 & 8.78 \\
\hline $\mathrm{SrO}$ & $<0.01$ & 0.01 & $<0.01$ & $<0.01$ & $<0.01$ & 0.01 & $<0.01$ & $<0.01$ & $<0.01$ & 0.01 & 0.01 & 0.02 & $<0.01$ & $<0.01$ \\
\hline $\mathrm{BaO}$ & 0.03 & $<0.01$ & 0.01 & $<0.01$ & 0.01 & $<0.01$ & 0.10 & 0.10 & 0.10 & 0.13 & 0.12 & 0.12 & 0.02 & 0.02 \\
\hline LOI & 5.05 & 0.95 & 5.07 & 0.66 & 2.10 & 0.98 & 1.04 & 1.08 & 1.10 & 0.70 & 0.73 & 0.67 & 1.37 & 1.37 \\
\hline Total & 98.76 & 99.40 & 91.16 & 101.27 & 98.23 & 99.86 & 99.11 & 100.40 & 100.62 & 100.79 & 101.10 & 100.23 & 94.81 & 96.39 \\
\hline
\end{tabular}

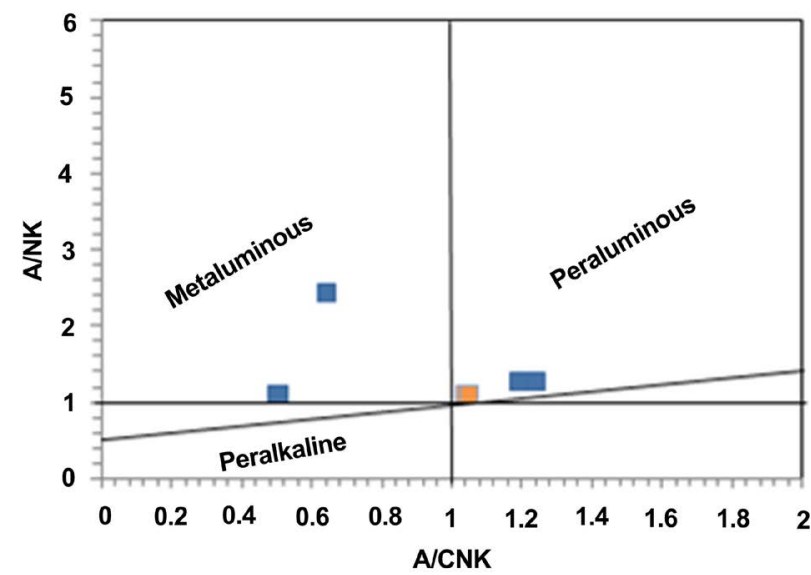

Gatumba

Gitarama

Figure 4. Plot of $\mathrm{A} / \mathrm{NK}$ versus $\mathrm{A} / \mathrm{CNK}$ for the pegmatites from Gitarama and Gatumba areas. (A/NK = molar ratio of $\mathrm{Al}_{2} \mathrm{O}_{3} /\left(\mathrm{Na}_{2} \mathrm{O}+\mathrm{K}_{2} \mathrm{O}\right)$; $\mathrm{A} / \mathrm{CNK}$ molar ratio of $\mathrm{Al}_{2} \mathrm{O}_{3} /\left(\mathrm{CaO}+\mathrm{Na}_{2} \mathrm{O}+\mathrm{K}_{2} \mathrm{O}\right)$, after [19].

( 20 ppm), Cs (5.47 - $5.62 \mathrm{ppm}), \mathrm{Ta}(1.3-1.6 \mathrm{pm})$ and $\mathrm{Rb}(321-337 \mathrm{ppm})$, such high enrichment implied the alteration process in metasedimentary intrusive body of pegmatite. The fresh pegmatite from Gitarama area show generally high concentration in $\mathrm{Ba}(893-929 \mathrm{ppm})$ content, pointing to a probably calc alkaline source [20]. The enrichment of $\mathrm{W}(\sim 10,000 \mathrm{ppm})$ was probably due to magmatic hydrothermal fluid circulated in granite and pegmatite where it has precipitated wolframite concentrates. 
Table 2. Trace element composition (ppm) of pegmatites and associated rocks from Gitarama and Gatumba areas.

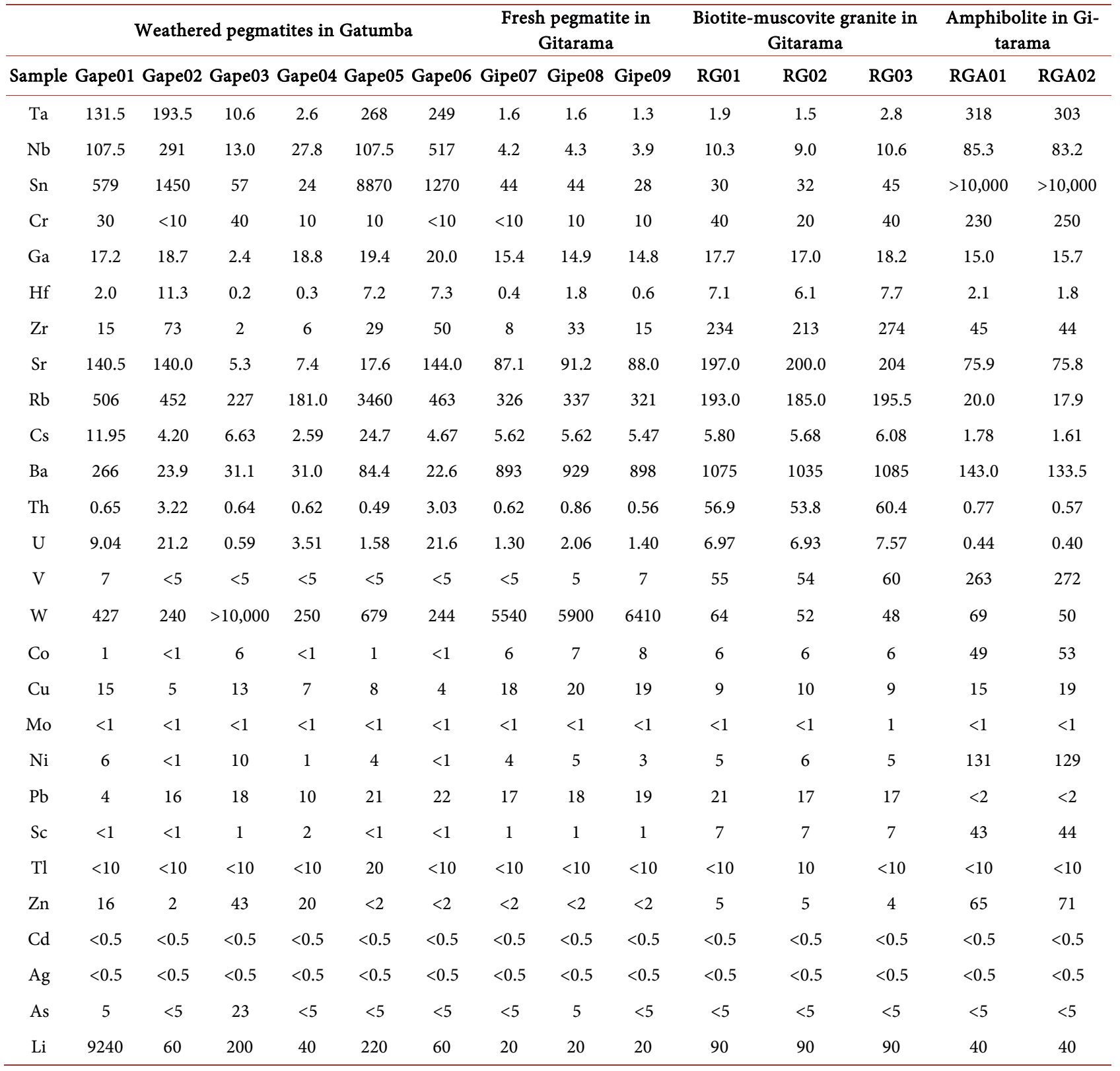

$<$ : below detection limit.

The abundance of $\Sigma$ REE in pegmatites from study areas ranged from 12.1 to $72.78 \mathrm{ppm}$ (Table 3) which implies rare element pegmatite. Chondrite diagram of REE showed the enrichment in LREE than HREE which also implied the high level of fractionation on the pegmatite from Gatumba and Gitarama areas. The fluids circulated and induced the precipitation of some rare and heavy metals. The Eu negative and positive anomalies (Figure 5) are associated with the plagioclase probably controlled the fractionation [21].

\subsubsection{Economic Mineralisation Aspect}

The $\mathrm{K} / \mathrm{Rb}$ values for the pegmatite from Gatumba and Gitarama areas ranged from 15.74 to 199.3 (Table 4). The pegmatites from Gatumba and Gitarama 
Table 3. Rare earth element composition ( $\mathrm{ppm}$ ) of pegmatites and associated rocks from Gitarama and Gatumba areas.

\begin{tabular}{|c|c|c|c|c|c|c|c|c|c|c|c|c|c|c|}
\hline \multirow[b]{2}{*}{ Sample } & \multirow[b]{2}{*}{ Gape01 } & \multicolumn{5}{|c|}{ Weathered pegmatites in Gatumba } & \multicolumn{3}{|c|}{$\begin{array}{c}\text { Fresh pegmatites in } \\
\text { Gitarama }\end{array}$} & \multicolumn{3}{|c|}{$\begin{array}{c}\text { Biotite-muscovite } \\
\text { granite } \\
\text { in Gitarama }\end{array}$} & \multicolumn{2}{|c|}{$\begin{array}{l}\text { Amphibolite } \\
\text { in Gitarama }\end{array}$} \\
\hline & & Gape02 & Gape03 & Gape04 & Gape05 & Gape06 & Gipe07 & Gipe08 & Gipe09 & RG01 & RG02 & RG03 & RGA01 & RGA02 \\
\hline $\mathrm{La}$ & 6.1 & 1.5 & 2.9 & 1.8 & 2.0 & 1.6 & 10.3 & 12.7 & 10.0 & 110.0 & 108.5 & 120.0 & 6.6 & 6.4 \\
\hline $\mathrm{Ce}$ & 12.5 & 3.4 & 8.3 & 3.3 & 3.9 & 3.6 & 14.3 & 16.4 & 14.6 & 189.0 & 186.0 & 213 & 8.0 & 7.1 \\
\hline $\operatorname{Pr}$ & 1.29 & 0.40 & 1.28 & 0.31 & 0.53 & 0.43 & 1.67 & 1.89 & 1.51 & 17.05 & 16.90 & 19.40 & 1.74 & 1.73 \\
\hline $\mathrm{Nd}$ & 5.3 & 1.8 & 6.6 & 1.1 & 2.4 & 2.1 & 6.8 & 8.0 & 6.1 & 55.8 & 54.1 & 61.5 & 7.4 & 7.7 \\
\hline $\mathrm{Sm}$ & 0.94 & 0.47 & 1.92 & 0.36 & 0.71 & 0.52 & 1.11 & 1.29 & 1.09 & 6.40 & 6.38 & 6.86 & 1.83 & 1.78 \\
\hline $\mathrm{Eu}$ & 0.20 & 0.20 & 0.84 & 0.04 & 0.09 & 0.19 & 0.58 & 0.62 & 0.56 & 1.39 & 1.42 & 1.44 & 0.68 & 0.62 \\
\hline $\mathrm{Gd}$ & 0.61 & 0.48 & 2.33 & 0.75 & 0.38 & 0.54 & 0.97 & 1.13 & 1.10 & 3.80 & 3.81 & 4.25 & 2.00 & 2.17 \\
\hline $\mathrm{Tb}$ & 0.10 & 0.09 & 0.48 & 0.17 & 0.03 & 0.08 & 0.15 & 0.19 & 0.17 & 0.48 & 0.54 & 0.50 & 0.35 & 0.37 \\
\hline Dy & 0.58 & 0.70 & 3.63 & 1.03 & 0.31 & 0.66 & 1.00 & 1.25 & 1.04 & 2.59 & 3.07 & 3.02 & 2.36 & 2.42 \\
\hline Ho & 0.09 & 0.15 & 0.98 & 0.18 & 0.07 & 0.14 & 0.21 & 0.25 & 0.21 & 0.53 & 0.55 & 0.63 & 0.52 & 0.48 \\
\hline $\mathrm{Er}$ & 0.20 & 0.42 & 3.51 & 0.52 & 0.15 & 0.41 & 0.55 & 0.81 & 0.61 & 1.66 & 1.71 & 1.89 & 1.51 & 1.50 \\
\hline $\mathrm{Tm}$ & 0.02 & 0.08 & 0.66 & 0.08 & 0.02 & 0.06 & 0.11 & 0.12 & 0.11 & 0.25 & 0.27 & 0.28 & 0.24 & 0.24 \\
\hline $\mathrm{Yb}$ & 0.11 & 0.54 & 5.11 & 0.59 & 0.18 & 0.53 & 0.63 & 0.88 & 0.80 & 1.63 & 1.57 & 1.75 & 1.26 & 1.44 \\
\hline $\mathrm{Lu}$ & 0.03 & 0.08 & 0.74 & 0.09 & 0.03 & 0.07 & 0.10 & 0.14 & 0.10 & 0.25 & 0.26 & 0.28 & 0.22 & 0.22 \\
\hline $\mathrm{Y}$ & 1.9 & 4.1 & 33.5 & 7.8 & 1.3 & 3.6 & 6.8 & 8.7 & 7.0 & 16.0 & 16.2 & 17.1 & 13.2 & 13.4 \\
\hline$\sum$ REE & 29.97 & 14.41 & 72.78 & 18.12 & 12.1 & 14.53 & 45.28 & 54.37 & 45 & 406.83 & 401.28 & 451.9 & 47.91 & 47.57 \\
\hline
\end{tabular}

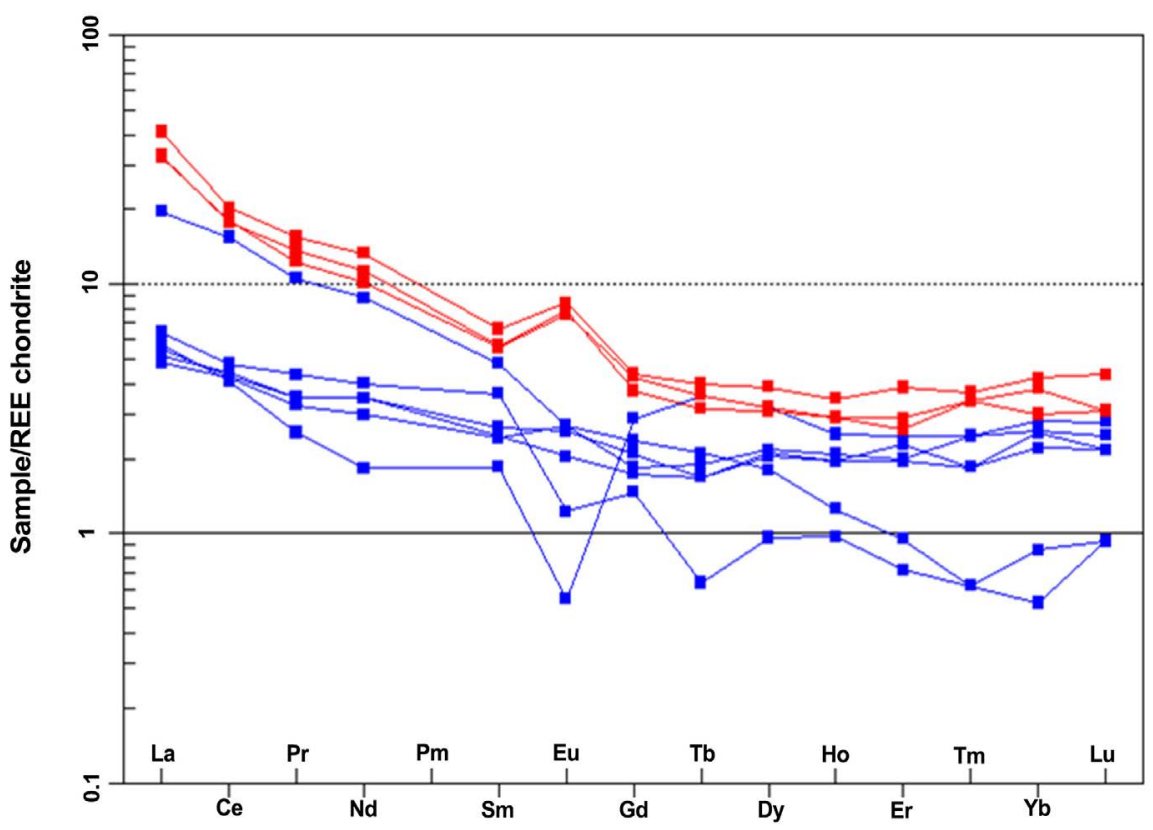

Figure 5. REE chondrite-normalised patterns showing the higher enrichment of LREE than HREE with negative and positive Eu anomalies for the pegmatites from Gatumba and Gitarama areas respectively, normalisation after [22]. 


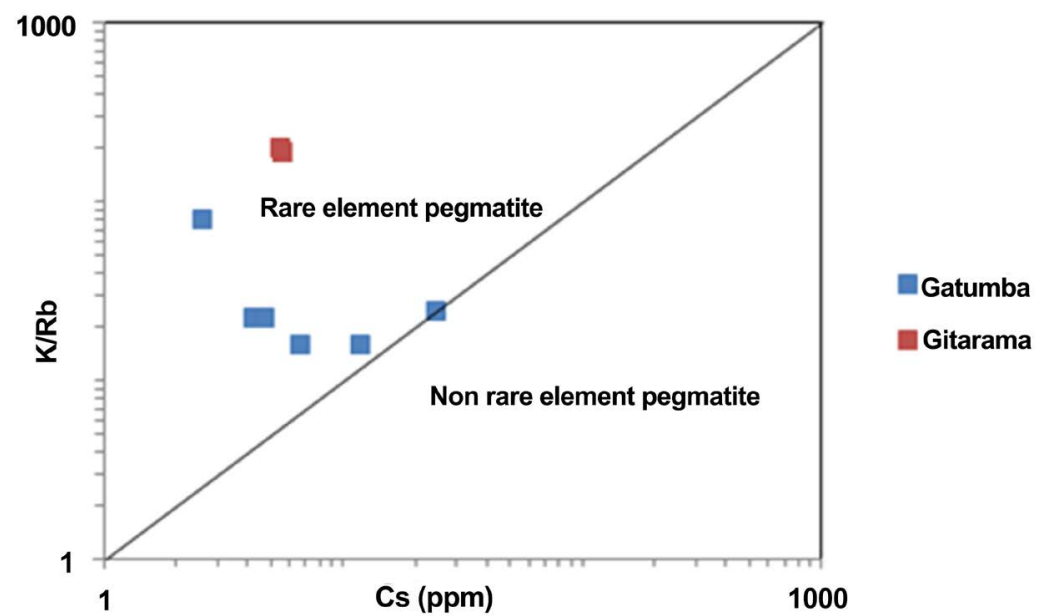

Figure 6. Plot of $\mathrm{K} / \mathrm{Rb}$ versus $\mathrm{Cs}$ for pegmatites from Gitarama and Gatumba areas, after [23].

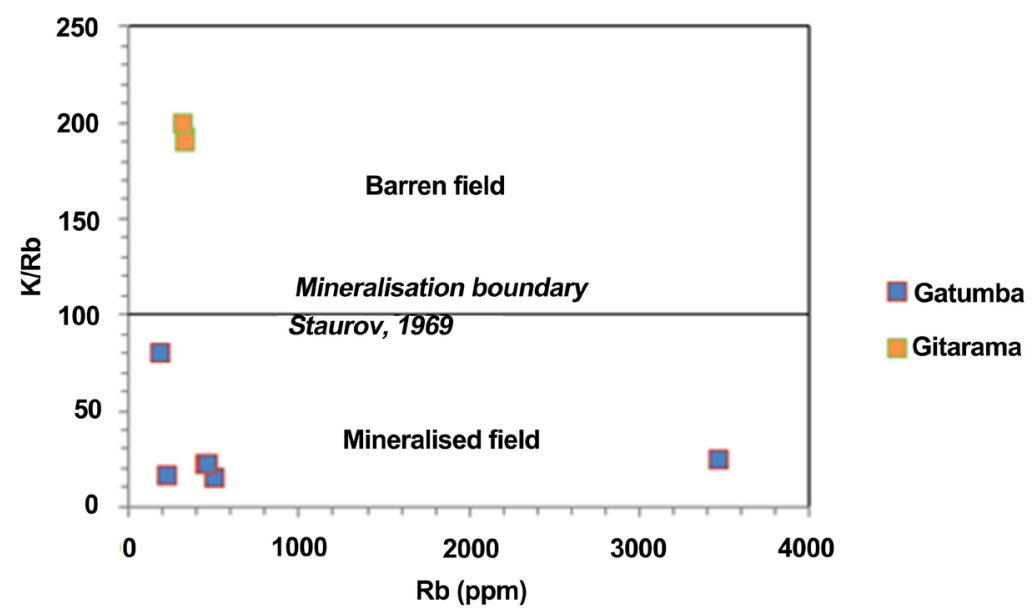

Figure 7. Plot of $\mathrm{K} / \mathrm{Rb}$ versus $\mathrm{Rb}$ for pegmatites from Gitarama and Gatumba areas, after [24].

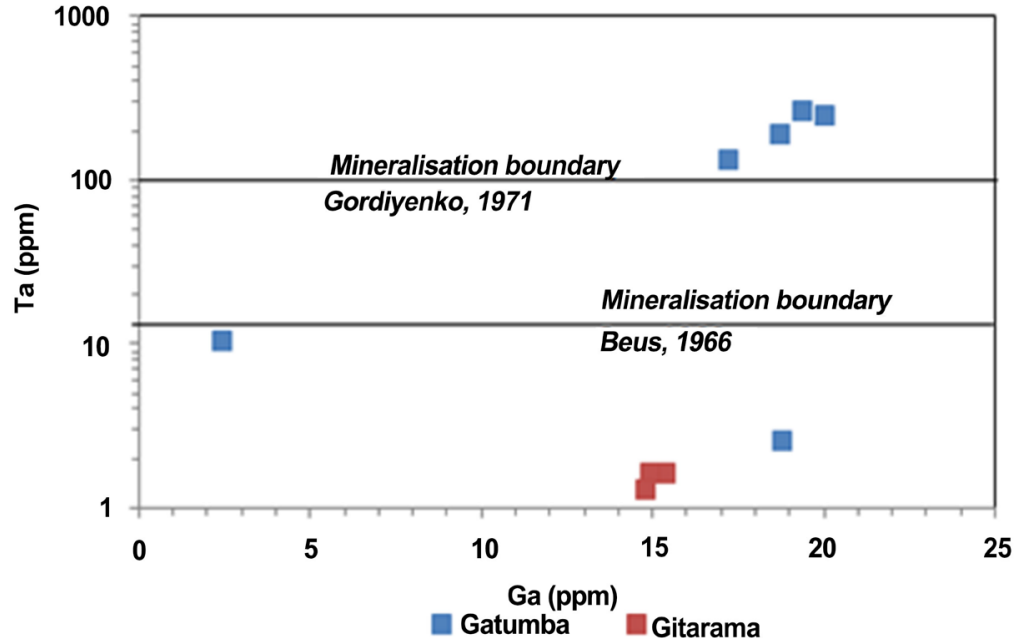

Figure 8. Plot of Ta versus Ga for pegmatites from Gitarama and Gatumba areas, after [25] [26]. 
Table 4. Elemental ratios of pegmatites and associated rocks from Gitarama and Gatumba areas.

\begin{tabular}{|c|c|c|c|c|c|c|c|c|c|c|c|c|c|c|}
\hline \multirow[b]{2}{*}{ Sample } & \multirow[b]{2}{*}{ Gape01 } & \multicolumn{4}{|c|}{ Weathered pegmatites in Gatumba } & \multirow[b]{2}{*}{ Gape06 } & \multicolumn{3}{|c|}{ Fresh pegmatite in Gitarama } & \multicolumn{3}{|c|}{$\begin{array}{c}\text { Biotite-muscovite granite } \\
\text { in Gitarama }\end{array}$} & \multicolumn{2}{|c|}{$\begin{array}{c}\text { Amphibolite in Gita- } \\
\text { rama }\end{array}$} \\
\hline & & Gape02 & Gape03 & Gape04 & Gape05 & & Gipe07 & Gipe08 & Gipe09 & RG01 & RG02 & RG03 & RGA01 & RGA02 \\
\hline $\mathrm{A} / \mathrm{CNK}$ & 7.65 & 0.51 & 0.64 & 1.19 & 1.24 & 0.50 & 1.05 & 1.04 & 1.05 & 1.02 & 1.03 & 1.03 & 0.56 & 0.54 \\
\hline $\mathrm{A} / \mathrm{NK}$ & 9.47 & 1.11 & 2.43 & 1.26 & 1.28 & 1.11 & 1.10 & 1.09 & 1.09 & 1.42 & 1.43 & 1.43 & 4.97 & 5.04 \\
\hline $\mathrm{K} / \mathrm{Rb}$ & 15.74 & 22.40 & 16.09 & 80.26 & 24.59 & 22.23 & 192.00 & 190.41 & 199.39 & 193.12 & 191.60 & 181.74 & 166.02 & 176.23 \\
\hline $\mathrm{K} / \mathrm{Cs}$ & 666.89 & 2411.38 & 550.92 & 5609.10 & 3444.94 & 2204.24 & $11,137.57$ & $11,418.23$ & $11,700.99$ & 6426.49 & 6240.72 & 5843.80 & 1865.50 & 1959.35 \\
\hline $\mathrm{Rb} / \mathrm{Ba}$ & 1.90 & 18.91 & 7.29 & 5.83 & 40.99 & 20.48 & 0.36 & 0.36 & 0.35 & 0.17 & 0.17 & 0.18 & 0.13 & 0.13 \\
\hline $\mathrm{Rb} / \mathrm{Sr}$ & 3.60 & 3.22 & 42.83 & 24.45 & 196.59 & 3.21 & 3.74 & 3.69 & 3.64 & 0.97 & 0.92 & 0.95 & 0.26 & 0.23 \\
\hline $\mathrm{Rb} / \mathrm{Cs}$ & 42.34 & 107.61 & 34.23 & 69.88 & 140.08 & 99.14 & 58.00 & 59.96 & 58.68 & 33.27 & 32.57 & 32.15 & 11.23 & 11.11 \\
\hline $\mathrm{K}_{2} \mathrm{O} / \mathrm{Na}_{2} \mathrm{O}$ & 3.84 & 0.16 & 44 & 0.38 & 4.70 & 0.17 & 3.62 & 3.64 & 3.68 & 1.47 & 1.40 & 1.42 & 0.30 & 0.29 \\
\hline $\mathrm{Nb} / \mathrm{Ta}$ & 0.81 & 1.50 & 1.22 & 10.69 & 0.40 & 2.07 & 2.62 & 2.68 & 3 & 5.42 & 6 & 3.78 & 0.26 & 0.27 \\
\hline $\mathrm{Zr} / \mathrm{Hf}$ & 7.50 & 6.46 & 10 & 20 & 4.02 & 6.84 & 2 & 18.33 & 25 & 32.95 & 34.91 & 35.58 & 21.42 & 24.44 \\
\hline
\end{tabular}

areas had $\mathrm{K} / \mathrm{Rb}$ ratios ranging from 15.74 to 80.26 and from 190.41 to 199.39 respectively. This implied that the pegmatites from Gatumba area were mineralised in columbite-tantalite and cassiterite whereas the pegmatite samples from Gitarama area were found barren [10]. Pegmatites with $\mathrm{K} / \mathrm{Rb}$ ratios less than 100 are generally accepted as mineralized pegmatites [24]. The K/Rb versus Cs plot (Figure 6) was also used to indicate rare element pegmatites after [23]. Further economic mineralization of these pegmatites from Gitarama and Gatumba areas was evaluated using variation plots of $\mathrm{K} / \mathrm{Rb}$ versus $\mathrm{Rb}$ (Figure 7) and Ta versus $\mathrm{Ga}$ (Figure 8) for their relationship to the mineralisation. The samples of mineralised pegmatite that plotted under the line of mineralisation boundary after [24] are the mineralised pegmatites from Gatumba area with low $\mathrm{K} / \mathrm{Rb}$ ratios below 100. Contrarily to the barren pegmatites from Gitarama area that were plotted above the mineralisation boundary of [24], and those are pegmatites with high ratios of K/Rb. Similarly, the plot Ta versus Ga showed the pegmatite from Gatumba area was mineralised, conversely to the pegmatite samples from Gitarama area which were found barren defined after the mineralisation boundaries of [25] [26].

\section{Conclusion}

The study investigated the petrography and geochemistry of pegmatites from Gitarama and Gatumba areas. Thus confirmed by the signature of quartz, biotite feldspars and dominant muscovite which revealed that the process of muscovitisation occurred after the emplaced primary pegmatite. The enrichment and high content of $\mathrm{Li}$, Cs, and $\mathrm{Rb}$ showed the magmatic hydrothermal alteration process occurred in the intrusive body of rare metal pegmatite in study areas. The various plots such as $\mathrm{K} / \mathrm{Rb}$ vs. $\mathrm{Rb}, \mathrm{Ta}$ vs. $\mathrm{Ga}$ and $\mathrm{K} / \mathrm{Rb}$ vs. Cs were also used to assess the mineralisation of pegmatites, which showed the pegmatite from Gatumba area was found mineralised, conversely to the pegmatite samples from Gitarama area which were found barren. The genesis of niobium-tantalum and tin minera- 
lisation and processes which occurred after primary emplacement of ores still remain questionable topics. Further research studies can be carried out using the isotopes (for example oxygen and hydrogen isotopes) in conjunction with fluid inclusion studies to obtain much more findings on the petrogenesis and kinds of fluids involved in processes subjected to these pegmatites.

\section{Acknowledgements}

The authors are grateful to the African Union Commission for granting scholarship and research grant for this intended work. Rwanda Mines, Petroleum and Gas Board (RMB) is acknowledged for providing the necessary facilities and relevant information to this research paper. Anonymous reviewers whose comments improved this manuscript are highly appreciated.

\section{Conflicts of Interest}

The authors declare no conflicts of interest regarding the publication of this paper.

\section{References}

[1] Dill, H.G. (2015) Pegmatites and Aplites: Their Genetic and Applied Ore Geology. Ore Geology Reviews, 69, 417-561. https://doi.org/10.1016/j.oregeorev.2015.02.022

[2] Pan, Y. and Breaks, F.W. (1997) Rare-Earth Elements in Fluorapatite, Separation Lake Area, Ontario; Evidence for S-Type Granite-Rare-Element Pegmatite Linkage. The Canadian Mineralogist, 35, 659-671.

[3] Tindle, A.G. and Breaks, F.W. (2000) Columbite-Tantalite Mineral Chemistry from Rare Element Granitic Pegmatites: Separation Lake Area, N.W. Ontario, Canada. Mineralogy and Petrology, 70, 165-198. https://doi.org/10.1007/s007100070002

[4] Bertossa, A. (1967) Inventaire des minéraux du Rwanda. Bulletin du Service Geologique de Rwanda, 4, 25-45.

[5] Pohl, W. (1994) Metallogeny of the Northeastern Kibara Belt, Central Africa-Recent Perspectives. Ore Geology Reviews, 9, 105-130. https://doi.org/10.1016/0169-1368(94)90024-8

[6] Tack, L., Fernandez-Alonso, M., De Waele, B., Tahon, A., Dewaele, S., Baudet, D. and Cutten, H. (2006) The Northeastern Kibaran Belt (NKB): A Long-Lived Proterozoic Intraplate History. In: 21st Colloquium African Geology (CAG21), 03-05.07.2006, Maputo, Mozambique, Abstract Volume, 149-151.

[7] Dewaele, S., Henjes-Kunst, S., Melcher, F., Sitnikova, M., Burgess, R., Gerdes, A., Fernandez Alonso, M., De Clercq, F., Muchez, P. and Lehmann, B. (2011) Late Neoproterozoic Overprinting of the Cassiterite and Columbite-Tantalite Bearing Pegmatites of the Gatumba Area, Rwanda (Central Africa). Journal of African Earth Sciences, 61, 10-26. https://doi.org/10.1016/j.jafrearsci.2011.04.004

[8] De Clercq, F. (2012) Metallogenesis of Sn and W Vein-Type Deposits in the Karagwe-Ankole Belt (Rwanda). PhD Thesis, Katholieke Universiteit Leuven, Leuven.

[9] Hulsbosch, N., Van Daele, J., Reinders, N., Dewaele, S., Jacques, D. and Muchez, P. (2017) Structural Control on the Emplacement of Contemporaneous Sn-Ta-Nb Mineralized LCT Pegmatites and Sn Bearing Quartz Veins: Insights from the Musha 
and Ntunga Deposits of the Karagwe-Ankole Belt, Rwanda. Journal of African Earth Sciences, 134, 24-32. https://doi.org/10.1016/j.jafrearsci.2017.06.004

[10] Hulsbosch, N., Hertogen, J., Dewaele, S., André, L. and Muchez, P. (2014) Alkali Metal and Rare Earth Element Evolution of Rock-Forming Minerals from the Gatumba Area Pegmatites (Rwanda): Quantitative Assessment of Crystal-Melt Fractionation in the Regional Zonation of Pegmatite Groups. Geochimica et Cosmochimica Acta, 132, 349-374. https://doi.org/10.1016/j.gca.2014.02.006

[11] Tack, L., Wingate, M.T.D., De Waele, B., Meert, J., Belousova, E., Griffin, B., Tahon, A. and Fernandez-Alonso, M. (2010) The 1375 Ma "Kibaran Event" in Central Africa: Prominent Emplacement of Bimodal Magmatism under Extensional Regime. Precambrian Research, 180, 63-84. https://doi.org/10.1016/j.precamres.2010.02.022

[12] Varlamoff, N. (1954) Repartition des types de pegmatites autour de la partie nord-ouest du grand massif granitique de Nyanza. Annales de la Société géologique de Belgique, 78, 1-21.

[13] Baudet, D., Hanon, M., Lemonne, E., Theunissen, K., Buyagu, S., Dehandschutter, J., Ngizimana, W., Nsengiyumva, P., Rusanganwa, J.B. and Tahon, A. (1988) Lithostratigraphie du domaine sédimentaire de la chaine Kibarienne au Rwanda. Annales de la Société géologique de Belgique, 112, 225-246.

[14] Ge'rards, J. (1965) Ge'ologie de la re'gion de Gatumba. Bulletin du Service Geologique de Rwanda, 2, 31-42.

[15] Cerny, P. (1991) Rare Element Granitic Pegmatites. Part I: Anatomy and Internal Evolution of Pegmatite Deposits. Geoscience Canada, 18, 49-67.

[16] Černý, P. and Ercit, T.S. (2005) The Classification of Granitic Pegmatites Revisited. The Canadian Mineralogist, 43, 2005-2026. https://doi.org/10.2113/gscanmin.43.6.2005

[17] Theunissen, K., Hanon, M. and Fernandez Alonso, M. (1991) Carte Geologique du Rwanda, 1:200 000. Service Geologique, Ministere de l'Industrie et de l'Artisanat, Republique Rwandaise.

[18] Lehmann, B., Halder, S., Munana, J.R., de la Paix Ngizimana, J. and Biryabarema, M. (2014) The Geochemical Signature of Rare-Metal Pegmatites in Central Africa: Magmatic Rocks in the Gatumba Tin-Tantalum Mining District, Rwanda. Journal of Geochemical Exploration, 144, 528-538. https://doi.org/10.1016/j.gexplo.2013.11.012

[19] Shand, S.J. (1943) Eruptive Rocks: Their Genesis, Composition, Classification, and Their Relation to Ore Deposits with a Chapter on Meteorites. John Wiley and Sons, New York, No. 552.1 S43 1943.

[20] Pichler, H. and Zeil, W. (1972) Chilean “Andesites" Crustal or Mantle Derivation. Proceedings of International Upper Mantle Project, Conference on Solid Earth Problems, Vol. 2, 361.

[21] Weill, D.F. and Drake, M.J. (1973) Europium Anomaly in Plagioclase Feldspar: Experimental Results and Semiquantitative Model. Science, 180, 1059-1060. https://doi.org/10.1126/science.180.4090.1059

[22] Boynton, W.V. and Henderson, P. (1984) Rare Earth Element Geochemistry.

[23] Möller, P. and Morteani, G. (1987) Geochemical Exploration Guide for Tantalum Pegmatites. Economic Geology, 82, 1888-1897. https://doi.org/10.2113/gsecongeo.82.7.1888

[24] Straurov, O.D., Stolyarov, I.S. and Isocheva, E.I. (1969) Geochemistry and Origin of Verkh Iset Granitoid Massif in Central Ural. Geochemistry International, 6, 
$1138-1148$.

[25] Gordiyenko, V.V. (1971) Concentration of Li, Rb, and Cs in the Potash Feldspar and Muscovite as Criteria for Assessing the Rare-Metal Mineralization in Granitic Pegmatites. International Geology Review, 13, 131-142.

https://doi.org/10.1080/00206817109475411

[26] Beus, A.A. (1966) Geochemistry of Beryllium and Genetic Types of Beryllium Deposits. W.H. Freeman, San Francisco, 401. 